\title{
A New Concept of Electrical-Equipment Explosion Protection Utilising Pressurised Enclosures and Stationary Nitrogen Installations
}

\author{
Nowa koncepcja ochrony przeciwwybuchowej urządzenia wykorzystująca osłonę \\ nadciśnieniową oraz stacjonarną instalację azotu \\ Новая концепция защиты устройства от взрыва, использующая защиту для высокого \\ давления и стационарной установки с азотом
}

\begin{abstract}
Aim: In the engineering practice, explosion protection is provided through the following steps: the elimination of the flammable material, the explosive atmosphere and the source of ignition. Another step is to limit the impact of the potential explosion. Electrical equipment might constitute the source of ignition for mixtures of flammable substances with air. The aim of the article is to present a new type of electrical equipment protection. According to the current technical standards, Ex p equipment is defined either as an enclosure with a constant static overpressure inside or purged enclosures with the use of clean air not containing flammable substances that could generate a hazardous atmosphere. This type of protection usually requires regular maintenance, complicated venting and/or frequent control of correct operation.

Project and methods: Electrical equipment designed to work in hazardous areas is designed with various types of protection ensuring safety in the case of a hazardous atmosphere created near the device. In order to present the concept of the new protection type, current technical standards were analysed to gather technical prerequisites. The Solid Edge environment was used to create 3D models of control and indicating equipment (CIE). The diagram presenting the concept of the whole device was also created. The aim of the project was to present the concept of the new mixed-type pressurised equipment.

Results: The design of the device proves that it is possible to create a new type of explosion protection of electrical equipment which has not been described in current technical standards. The concept assumes the use of stationary compressed nitrogen installations present in many factories. The installation will maintain a constant positive pressure inside the enclosure. It is also feasible to use portable inert gas tanks, which will require additional means of protection. The proposed design was checked against the set requirements. For the designed equipment, ready formulae were used to determine screw tightening torques in order to activate the device after exceeding specific parameters, such as the gas flow rate.

Conclusions: The current technical standards give space for designing a new type of electrical equipment protection. The article describes the outcomes of the research and project work conducted to visualise the concept. These types of equipment protection can be certified for all working conditions, which increases their applicability potential.
\end{abstract}

Keywords: ex equipment, electrical devices, explosion protection, pressurised enclosure

Type of article: original scientific article

Received: 30.11.2017; Reviewed: 14.01.2018; Accepted: 10.04.2018;

Please cite as: BiTP Vol. 49 Issue 1, 2018, pp. 94-100, doi: 10.12845/bitp.49.1.2018.9;

This is an open access article under the CC BY-SA 4.0 (https://creativecommons.org/licenses/by-sa/4.0/).

\section{ABSTRAKT}

Cel: W praktyce inżynierskiej ochrona przed wybuchem polega na eliminacji materiału palnego, atmosfery wybuchowej oraz źródła zapłonu. Kolejnym krokiem jest ograniczenie możliwych skutków wybuchu. Potencjalnym źródłem zapłonu mieszaniny powietrza z materiałem palnym są urządzenia elektryczne. Celem artykułu jest zaprezentowanie nowej koncepcji budowy przeciwwybuchowej tego typu urządzeń. Obowiązujące normy opisują urządzenia Ex p jako utrzymujące stałe nadciśnienie wewnątrz obudowy lub jako wentylowane powietrzem niezanieczyszczonym gazami palnymi. Zapewnienie ochrony przeciwwybiuchowej urządzeń tego typu jest jednak problematyczne, ponieważ wymaga skomplikowanego układu instalacji wentylacyjnej, a także częstej kontroli pracy.

Projekt i metody: Urządzenia elektryczne przeznaczone do użytkowania w przestrzeniach zagrożonych wybuchem konstruowane są z wykorzystaniem różnego rodzaju założeń bezpieczeństwa na wypadek wystąpienia atmosfery wybuchowej. W celu przedstawienia nowej koncepcji ochrony przeciwwybuchowej dokonano analizy obowiązujących norm oraz określono zbiór założeń projektowych. Wykorzystano środowisko Solid Edge do stworzenia 
modeli 3D urządzeń kontrolnych i sterujących. Następnie opisano schemat blokowy najistotniejszych części urządzenia. Celem prac projektowych było zaprezentowanie nowej mieszanej koncepcji budowy przeciwwybuchowej urządzeń elektrycznych, którą nazwano roboczo Ex pN.

Wyniki: Zaprojektowane rozwiązanie dowodzi, że możliwe jest stworzenie nowej budowy przeciwwybuchowej urządzeń, nieopisanej w normach. Wykorzystuje ona stacjonarne instalacje ze sprężonym azotem obecne w wielu zakładach produkcyjnych. Utrzymują one stałe nadciśnienie gazu inertnego wewnątrz obudowy urządzenia. Możliwe jest także wykorzystanie przenośnych zbiorników z gazem obojętnym, które wymaga jednak zastosowania dodatkowych środków bezpieczeństwa. Proponowane rozwiązania sprawdzono pod względem postawionych założeń projektowych. Dla zaprojektowanych urządzeń podano gotowe wzory do wyznaczenia momentów siły, jaką należy przyłożyć do śrub regulacyjnych, aby uruchomienie nastąpiło po przekroczeniu określonego parametru pracy urządzenia, np. prędkości przepływu gazu.

Wnioski: Aktualne normy techniczne pozwalają na projektowanie urządzeń elektrycznych w wykonaniu przeciwwybuchowym. Urządzenia tego typu mogą być certyfikowane do uniwersalnych zastosowań, co podnosi ich potencjał aplikacyjny. W artykule zaprezentowano także koncepcję dalszych badań.

Przyjęty: 30.11.2017; Zrecenzowany: 14.01.2018; Zatwierdzony: 10.04.2018;

Proszę cytować: BiTP Vol. 49 Issue 1, 2018, pp. 94-100, doi: 10.12845/bitp.49.1.2018.9;

Artykuł udostępniany na licencji CC BY-SA 4.0 (https://creativecommons.org/licenses/by-sa/4.0/).

\section{АННОТАЦИЯ}

Цель: В инженерной практике защита от взрыва заключается в устранении горючего материала, взрывоопасной атмосферы и источника воспламенения. Следующий шаг - ограничить возможные последствия взрыва. Потенциальным источником воспламенения воздушной смеси с горючим материалом являются электрические устройства. Цель статьи - представить новую концепцию взрывобезопасного строения этого типа устройств. Действующие стандарты описывают устройства Ех р, как такие, которые поддерживают постоянное высокое давление внутри корпуса или как устройства, вентилируемые воздухом, не содержащим легковоспламеняющихся газов. Однако, обеспечение защиты от взрыва этого типа устройств является проблематичным, так как для этого требуется сложная система вентиляции, а также частый контроль работы

Проект и методы: Электрические устройства, предназначенные для использования в потенциально взрывоопасных средах, конструируются с использованием различных концепций безопасности в случае появления взрывоопасной атмосферы. Чтобы представить новую концепцию взрывозащиты, были проанализированы существующие стандарты и определен ряд предположений для данного проекта. Среда Solid Edge использовалась для создания трехмерных моделей устройств контроля и управления. Далее описывается блок-схема наиболее важных частей устройства. Цель работы над проектом - представить новую смешанную взрывозащиты электрических устройств, которую называли Ех pN.

Результаты: Разработанное решение доказывает, что можно создать новую взрывозащищенную конструкцию устройства, не описанную в стандартах. Она использует стационарные установки со сжатым азотом, присутствующими на многих производственных предприятиях. Они поддерживают постоянное высокое давление инертного газа внутри корпуса устройства. Возможно также использование переносных емкостей инертного газа, которые, однако, требуют дополнительных мер безопасности. Предлагаемые решения были проверены с точки зрения заложенных предположений для данного проекта. Для уже разработанных устройств были приведены готовые формулы с определением момента силы, которую должны применять к регулировочным болтам, так чтобы запуск происходил после превышения для определения параметра работы устройства, например скорости потока газа.

Выводы: Действующие технические стандарты позволяют разработать взрывозащищенное электрооборудование. Устройства этого типа могут быть сертифицированы для универсального использования, что увеличивает их потенциал применения. В статье также представлена концепция дальнейших исследований.

Ключевые слова: proszę uzupełnić

Вид статьи: оригинальная научная статья

Принята: 30.11.2017; Рецензирована: 14.01.2018; Одобрена: 10.04.2018;

Просим ссылаться на статью следующим образом: BiTP Vol. 49 Issue 1, 2018, pp. 94-100, doi: 10.12845/bitp.49.1.2018.9;

Настоящая статья находится в открытом доступе и распространяется в соответствии с лицензией CC BY-SA 4.0 (https://creativecommons.org/ licenses/by-sa/4.0/).

\section{Introduction}

The production process of many goods is inseparably associated with flammable substances in the form of gas, vapour and dust. The most typical processes in which the explosion hazard should be taken into account are plastics production, equipment painting, printing, refinement, electronic components production and chemical compounds synthesis. On the other hand, all processes in which flammable solid materials are processed should be connected with the probability of explosive dust-air cloud formation. Ensuring the appropriate level of explosion safety through risk analysis is therefore the responsibility of the company owner [1], who in fact makes the workplace available to employees.

Most of the described examples - technological processes - would not be possible without the use of various electrical devices. According to the state of the art, there are 13 potential ignition sources [2] to be recognised and analysed during explosion risk assessment. The majority is connected with the use of electrical devices. In typical industrial applications the following are of pivotal importance:

Electrical devices - the energy stored within the electrical circuit of a device, if discharged instantaneously, might lead to the ignition of a hazardous atmosphere. 
Surface temperature - if the hot surface temperature exceeds the ignition temperature of a particular substance, it may cause ignition. In the case of gases and vapours, it is known as the Zeldovich Mechanism and has been well described in the literature, e.g. [3]. In terms of combustible dusts, firstly the thermal decomposition will take place and, subsequently, the ignition of the material.

Static electricity - all physical objects have certain capacitance, which is not necessarily easy to equalise by grounding connections, e.g. in the case of non-conductive materials. The electric charge may become an effective source of ignition.

Mechanical sparks - if the device consists of rotating parts, in some specific conditions mechanical sparks may be created. They usually carry a sufficient quantity of energy to cause the ignition of a hazardous atmosphere. In general, mechanical sparks are generated during the collision of two bodies.

After the introduction of electrical devices into the mines, the first research about the explosion protection was carried out, resulting in the technical standard issued by the VDE (ger. Verband Deutscher Elektrotechniker) in 1912. The flameproof protection of electrical motors was described for the first time. After decades of technological development, there are plenty of possible ways to ensure the explosion safety of the equipment. Most important are the following:

Flameproof protection (Ex d) - if the explosion is induced inside the enclosure, the appropriate geometry of the enclosure joint will prevent the flame to propagate to the exterior of the device [4].

Increased safety (Ex e) - electric arcs and mechanical sparks generation during the normal operation of the equipment are controlled, as well as the maximum surface temperature [5].

Intrinsic safety (Ex i) - the energy stored within the electrical circuit is limited to a safe level; in the case of a failure, the discharged energy would be too low to cause the ignition of a hazardous atmosphere [6].

Encapsulation (Ex m) - the electrical circuit is encapsulated by the thermosetting polymer, which will prevent the physical contact between the ambient (hazardous) atmosphere and the potential source of ignition within the circuit [7]. A similar concept with a different immersion medium was used in powder filling enclosures (Ex q) [8] and oil immersion (Ex o) [9].

Pressurisation (Exp) - overpressure in the enclosure is created to prevent the ambient atmosphere from the housed electrical equipment [10]. It is also possible to maintain a positive pressure in the compartment, where the equipment was located [11].

There are two solutions distinguished in the standard describing the protection by the increase of the pressure inside the enclosure. In the first one, a static overpressure is created and maintained inside the hermetically sealed enclosure. The second one describes technical requirements for the devices that are purged constantly with clean gas, which can be atmospheric air, if the absence of flammable substances is assured. This type of protection is commonly used around the world. There are many international standards, tailor-made for the legislation of particular countries. The requirements of these standards are similar, which was described in [12]. There are three categories of pressurised and purged equipment making it possible to decrease the required EPL: Ex pz - from ' $c$ ' to non-hazardous; Ex py - from ' $b$ ' to ' $c$ '; Ex px - from ' $b$ ' to non-hazardous.

One of the most commonly used electrical device in the industry is electrical motor. Usually Ex d (flameproof protection), often connected with Ex e (increased safety) types of protection are used to achieve an acceptable level of safety. In the petrochemical industry, Ex $\mathrm{p}$ (pressurised) equipment is commonly used. The state of the art will provide the designers with empirical data concerning the optimal minimum overpressure, purging times, as well as the typical temperature rise of the windings and the motor body [13].

Pressurised equipment does not necessarily need to be stationary. There are some implementations in which the device is equipped with a portable gas tank, ensuring appropriate overpressure inside the enclosure even in the case of intermediate leakage. The example might be the mobile robot, designed to detect the presence of toxic and flammable gases in the coal mine [14].

The aim of this article is to present the concept of a mixed type of Ex $p$ equipment, in which a static overpressure will be created inside the enclosure. A connection to the nitrogen installation, commonly used in many factories, will enable the automatic control of pressure inside the enclosure. It will constitute the cooling medium in the case of enclosure rupture as well. The use of portable gas tanks is also possible.

\section{Methods}

The aim of the presented research has been to create a concept for mixed-type pressurised equipment which has not been described directly either in standard [10] nor [11]. However, technical requirements are fulfilled by the proposed solution. An example of control and indicating equipment was designed to visualise the proposed concept, and the principle of operation was described with the use of physical relationships.

Among the most crucial technical requirements, the following should be mentioned:

- The enclosure should be filled by the gas that will not contain flammable components.

- The piping system and wires should be inserted inside the enclosure with the use of ducts of a specific flame resistance, not less than $\mathrm{V}-0$ [15].

- The equipment within the enclosure should have a source of energy separate from the common electric wiring.

- The enclosure should be equipped with a pressure sensor, protecting from an overpressure drop below $50 \mathrm{~Pa}$. The high pressure side of the sensor should not be covered from the inner atmosphere (e.g. by filter, valve).

- The purged enclosure should be protected from the loss of the gas flow.

- The enclosure should be hermetically sealed.

- The protective gas supply should maintain a positive pressure.

- The minimum IP code of the enclosure should be IP4X.

- The enclosure should be resistant to mechanical impact. 
- Any hot surfaces inside the enclosure should be cooled down before the enclosure is opened.

- The position of the inlet and outlet of purge gas should depend on its relative density.

- If vents are provided, the spark and solid particle barrier must be present.

- It must be possible to check the operation of the control and indicating equipment.

- Appropriate marking should be placed on the enclosure (e.g. about the overpressure inside the enclosure).

- The redundancy of the automatic safety devices is necessary.

- The equipment should not be energised before the concentration of flammable gas drops down below the $25 \%$ of the limiting value.

- The volume of the enclosure should be purged at least five times before the equipment will be energised.

To visualise the potential of the proposed solution, the example of automatic safety devices was created. The Solid Edge ST9 environment was used for this purpose. The design was adjusted and cross-checked against the requirements given above.

\section{Outcomes}

The main concept of Ex p equipment is to maintain a positive pressure inside the enclosure of the electrical device. It will prevent the penetration of a hazardous atmosphere which might be created outside the device. The presented concept is based on the assumption to maintain a static overpressure inside the enclosure and to use the stationary nitrogen installation not for purging but to avoid pressure drop down in a hermetically sealed housing.

As described before, the device must fulfill some requirements. The examples of CIE (control and indicating equipment) were therefore designed to visualise the concept. To prove the implementation potential, they are based on the existing solutions. As the whole enclosure may be subject to an EU-type examination, within certain limits, the concept is universal.

The first element ensuring the sufficient level of safety is the pressure relief valve. Its role is to prevent an excessive increase of pressure inside the enclosure. The designed application was shown below.

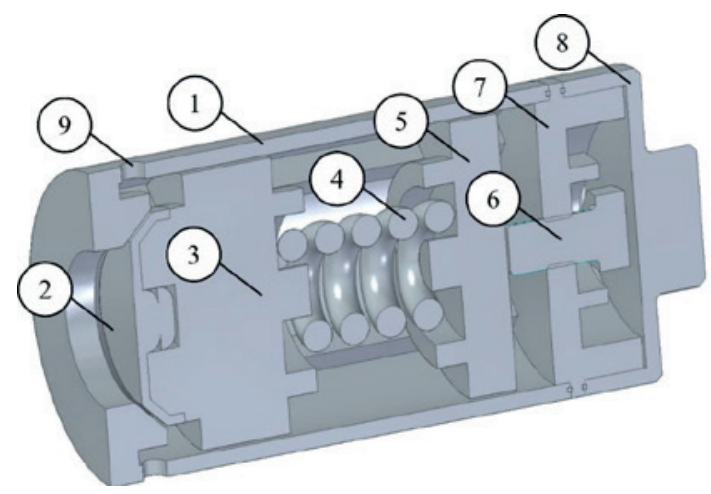

Figure 1. The cross-section of the pressure relief valve 3D model Source: Own elaboration.

The body (1) is attached to the enclosure, so the inert gas exerts pressure on the valve stem (3). The tightness is ensured by the conical cup seal (2). The set up override pressure is kept by the spring (4) held in an auxiliary position by the seat (5). The calibration of the spring is ensured by the set screw (6) supported by the cup (7). The last part is the cover (8). If the pressure inside the housing increases above the threshold, the gas will flow through the openings (9). The set screw (as well as the cup) should have a trapezoidal buttress thread, which handles high axial thrust, but only in one direction. The spring should work within the limits of its own linear characteristics, i.e. within the applicability of the Hook's Law. By neglecting the friction between the valve stem, the cup and the body, and between the valve stem and the set screw, the tightening torque can be calculated on the basis of the following formula:

$$
M=\frac{p A}{2}\left(d_{2} \tan \left(\gamma+\rho^{\prime}\right)+D_{N} \mu_{N}\right)
$$

where: $M$ - screw tightening torque [Nm]; $p$ - overpressure inside the enclosure $[\mathrm{Pa}] ; A-$ the surface area of the valve stem $\left[\mathrm{m}^{2}\right] ; d_{2}$ - equivalent diameter of the set screw $[\mathrm{m}] ; \gamma$-lead angle of the set screw thread [ ${ }^{\circ}$ ]; $\rho$ ' - apparent friction angle of the set screw thread $\left[^{\circ}\right] ; D_{N}$ - nominal diameter of the cup thread [m]; $\mu_{N}$ - coefficient of the friction between the set screw and the cup threaded hole [-].

The initial stress generated by the spring will be balanced by the pressure inside the enclosure according to the following formula:

$$
p A=k x
$$

where: $k$ - spring constant $[\mathrm{N} / \mathrm{m}] ; x$ - displacement of the spring $[\mathrm{m}]$.

The screw tightening torque reflects the given balance condition. When the relief pressure valve opens, the pressure on both sides of the valve stem will equalise. The tension created by the spring will cause the valve to close again. As soon as the atmospheric pressure is restored inside the valve (providing the pressure inside the enclosure is still too high), it will open again, which will cause the oscillation of the valve stem, well known in similar designs.

The second device was designed to prevent the pressure drop-down inside the enclosure. The cross-section of the $3 \mathrm{D}$ model was shown below. 


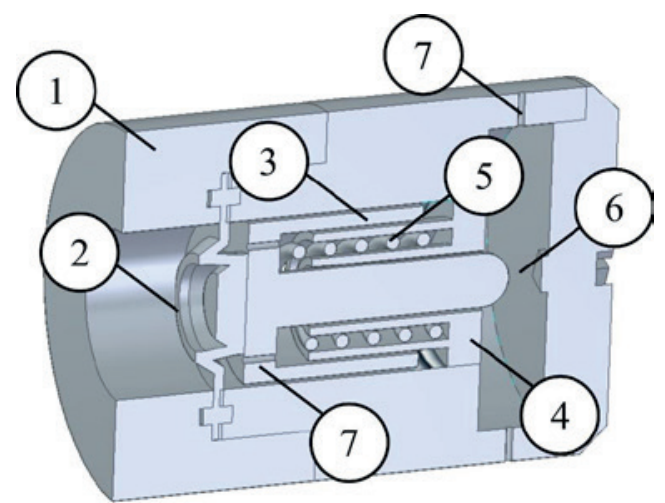

Figure 2. The cross-section of the pressure sensor 3D model

Source: Own elaboration.

The left side of the body (1) (high-pressure side) is attached to the enclosure. The inner atmosphere exerts pressure on the membrane (2). The force is created resulting in the valve stem (3) movement. It is at the same moment the cup for the spring (5). The other side of the spring is kept in its position by the spring nest (4). The contacts (6) create the electrical signal (electrical connections were not shown on the model). The outer atmosphere exerts pressure on the low-pressure side of the device thanks to special holes (7). As the inner part of the device should be protected from the hazardous atmosphere, it should be connected by the pipe with a highly elastic membrane (not shown on the model).

The pressure threshold can be designed in many ways, i.e.: by selecting the spring of a certain spring constant, by a certain length of the contact, by selecting the thickness of the membrane, which affects its susceptibility to displacement caused by the exerted pressure. The calibration is conducted by screwing the spring nest to the appropriate position (4). The spring nest and the body should have a trapezoidal buttress thread (self-locking thread).

In this case, the balance equation will be as follows:

$$
p A=\left(k-k_{1}\right) x
$$

where: $k_{1}$ - constant factor characteristic of the membrane [N/m].

It should be noted that the membrane can be anisotropic. However, the appropriate shape of the membrane might cause this property to be negligible. By using the above mentioned balance formula (spring nest displacement $x$ is known this time), the same formula (1) can be used to determine the spring nest's tightening torque.

Low voltage should be used to energise the circuit. As the potential hazardous atmosphere is separated from the contacts, and the other parts of it are immersed by the inert gas, there is no need to ensure intrinsic safety. However, low voltage will decrease the possibility of electric arc creation during the contacts divergence. Moreover, if the decrease of the inner pressure is slow, the contacts divergence will also proceed slowly, which might cause the increase of contact resistance. To achieve a higher sensitivity of the sensor, the current can be monitored. In the case of a sudden pressure drop-down, the contacts will open immediately, and the sensor will generate the signal.

The pressure sensor may also be used to react when the pressure inside the enclosure exceeds the safe value. The generated signal can be used to stop the gas flow and to de-energise the protected device.

The device should also be equipped with a flow-rate sensor. In the case of an enclosure rupture, the inner pressure will drop down. The inert gas installation will keep the pressure at the desired level. However, in some specific conditions, the pressure sensor will be held in its initial position, not generating the signal for the switch to deactivate the device. In that situation, the flow-rate sensor will generate the signal. The cross-section of the sensor 3D model was shown below.

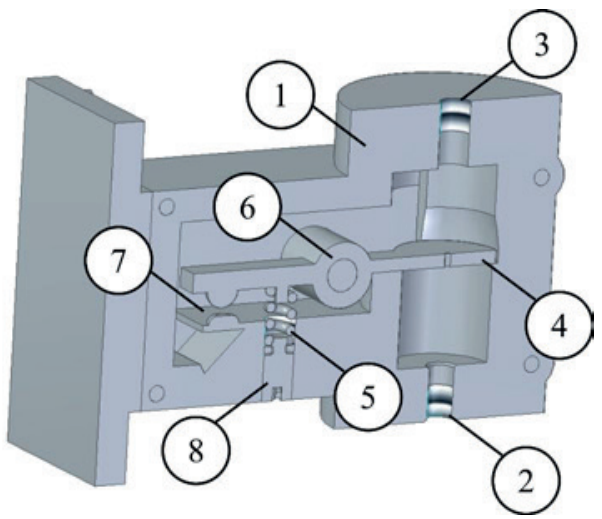

Figure 3. The cross-section of the flow-rate sensor 3D model

Source: Own elaboration. 
The body (1) has two openings: inlet (2) and outlet (3). The chamber is closed by the valve (4). The flow of the inert gas will exert pressure on the valve (4). The contact (7) will be closed if the pressure is high enough to overcome the force created by the spring (5). The force generated by the spring can be regulated by the use of the set screw (8).

There is a number of possibilities to design the desired flow rate causing the contacts to be closed, i.e. the diameter of the centric hole in the valve (4); the position of the hinge (6), the modification of the moment of force created; the characteristics of the spring (5). During the operation, the set screw (8) should be used for the purpose of sensor calibration. The self-locking thread should also be applied here.

In the case of the flow-rate sensor, the determination of the set screw tightening torque is more complicated. First, the moment of the force balance formula should be analysed.

$$
a Q_{s}=b Q_{f}
$$

where: $a$ - distance between the hinge and the spring nest placed on the valve [m]; $Q_{s}$ - force to be created by the spring $[\mathrm{N}] ; b$ - distance between the hinge and the centre of the valve disk (imaginary position of force $Q_{f}$ vector) $[\mathrm{m}] ; Q_{f}$ - imaginary force (created by the pressure) vector [N].

To find the relationship between the flow rate and force exerted by the differential pressure on both sides of the valve, flow continuity equation (5) and energy equation (6) must be presented, assuming the gas is compressible. The subscript value ' 1 ' is used to describe the inlet-side parameters, value ' 2 ' to describe the outlet-side of the sensor.

$$
\begin{array}{r}
\rho_{1} V_{1} d_{1}^{2}=\rho_{2} V_{2} d_{2}^{2} \\
\frac{V_{1}^{2}}{2}+\frac{k}{k-1} \frac{p_{1}}{\rho_{1}}=\frac{V_{2}^{2}}{2}+\frac{k}{k-1} \frac{p_{2}}{\rho_{2}}
\end{array}
$$

where: $\rho$ - density of the gas $\left[\mathrm{kg} / \mathrm{m}^{3}\right] ; V$ - speed of the gas $[\mathrm{m} / \mathrm{s}]$; $d$-diameter of the duct [m]; $k$ - heat capacity ratio of the gas $[-] ; p$ - gas pressure $[\mathrm{Pa}]$.

Assuming there is no pressure loss (isentropic process) and introducing the following equations of orifice module $m$ and differential pressure $\Delta p$ :

$$
\begin{gathered}
m=\left(\frac{d_{2}}{d_{1}}\right)^{2} \\
\Delta p=p_{1}-p_{2}
\end{gathered}
$$

the relationship between flow rate $q$ and differential pressure $\Delta p$ can be transformed to the following formula:

$$
\Delta p=\frac{8\left(1-m^{2}\right) \rho_{1} q^{2}}{m^{2} \pi^{2} \varepsilon^{2} d_{1}^{4}}
$$

where: $\varepsilon$ - expansion number connected with gas compressibility [-]; it is the (linear) function of the orifice module and the pressure ratio: $\varepsilon=f\left(m, \Delta p / p_{1}\right)$.

There is an empirical formula available (10) to approximate the expansion factor for the ISA orifice plate:

$$
\varepsilon=1-\left(0,3703+0,3184 \times m^{2}\right)\left[1-\left(1-\frac{\Delta p}{p_{1}}\right)^{\frac{1}{k}}\right]^{0,935}
$$

The value of calculated $\Delta p$ will in fact exert pressure on the inlet-side of the valve inside the flow-rate sensor. By substituting $\Delta p$ to equation (1), the set screw tightening torque can be determined.

The concept of the device assembly was presented in following figure.

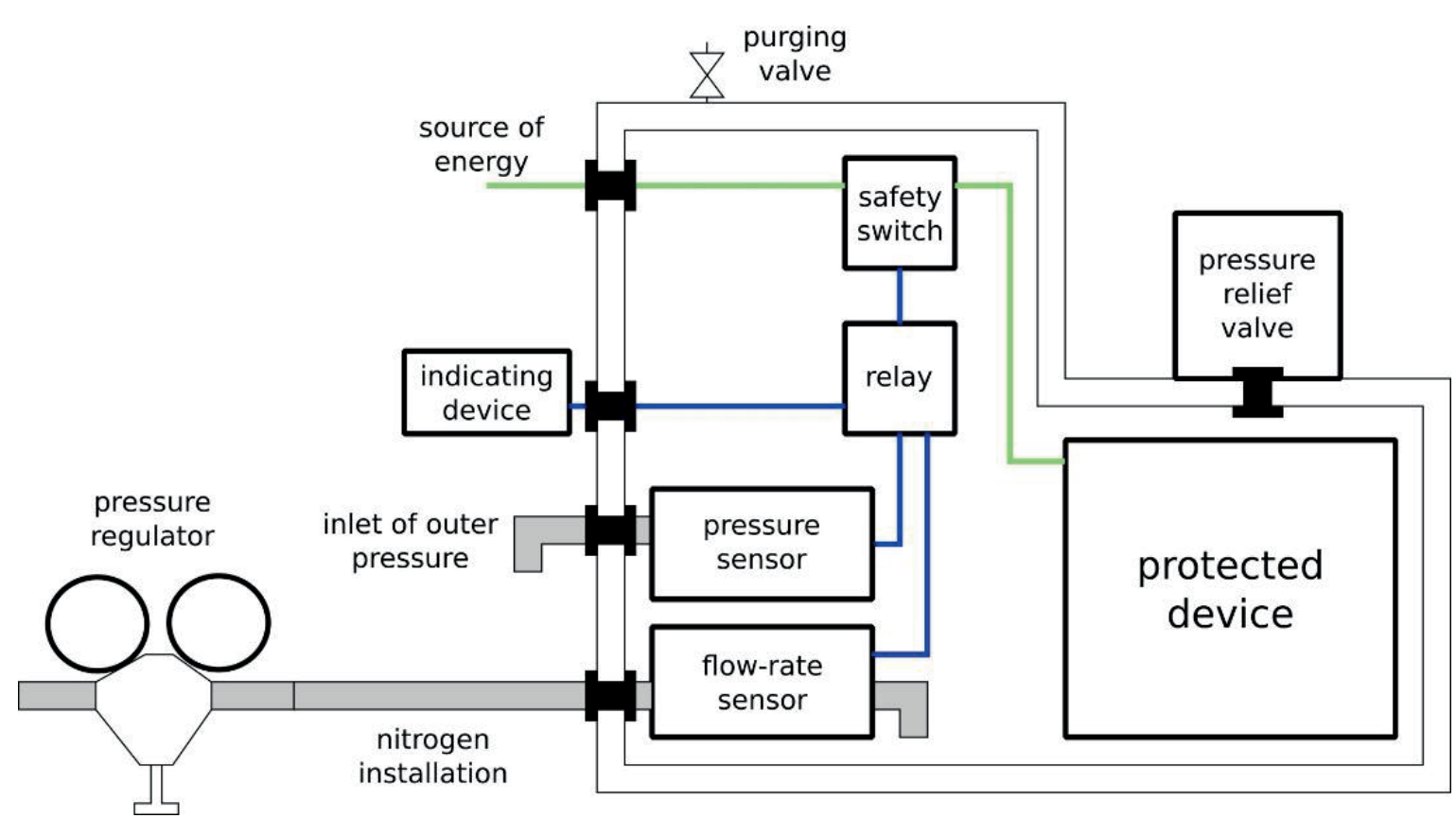

Figure 4. The concept of mixed-type Ex p protection device Source: Own elaboration. 
A positive pressure inside the enclosure is ensured by the stationary nitrogen installation, however, portable gas tank might also be used. The relay will turn off the safety switch if the signal was generated by the pressure sensor (too low pressure inside the enclosure) or flow-rate sensor (flow rate too high). At the same time, the signal should be sent to the indicating device. It can be placed outside the enclosure, but in that case it should have a special hermetically sealed housing to avoid the necessity to design intrinsically safe electrical circuits. The pressure relief valve will protect the enclosure from the excessive increase of the inner pressure.

\section{Discussion}

The presented concept constitutes the basis for the detailed design of a new type of protection for electrical equipment dedicated to operate in hazardous areas. The concept connects both purging and maintaining a static pressure inside the enclosure, which have been described in technical standards. To prove the applicability potential, the concept was cross-checked against the technical requirements.

In the real application, the ducts should have a sufficient flame resistance and should allow safe operation within the designed positive pressure range. The minimum overpressure should not be lower than $50 \mathrm{~Pa}$.

The enclosure should withstand the mechanical impact. Its value should be determined according to the desired application. Also the maximum surface temperature of the device should be determined to assign the appropriate temperature class of the device. If the surface of the protected device can be the source of ignition, before the enclosure is opened, it should be cooled down. An additional circuit to control solenoid valves on the inert gas piping and/or purging valve might be considered.

Some specific procedures should be designed for the safe operation of the device. Also a precise calibration and verification of the correct operation is crucial. Energising the equipment should not take place before the enclosure volume is purged at least five times.

The presented concept of the device only shows the ideological diagram. The redundancy of the control and indicating equipment should be assured.

\section{Conclusions}

1. Pressurised equipment (Exp) is commonly used in various industries. However, the potential gap of the technical standard [10] was identified. Inside the enclosure a static overpressure can be ensured by hermetical sealing or by the constant flow of clean air/inert gas. The article presents the concept of mixed-type protection, which is not covered directly by the technical standard.

2. The presented concept has an applicability potential, as nitrogen installations are commonly used in many industries, which might be helpful in ensuring a longer operation of the enclosure without maintenance.
3. The example of crucial control and indicating equipment has been designed and some physical formulae have been used to describe its operation and calibration principles.

4. The concept may be developed for tailor-made solutions appropriate for a particular application.

5. The presented concept makes it possible to lower the required equipment protection level from ' $a$ ' to none if the given requirements are fulfilled.

\section{Literature}

[1] Directive 2014/34/EU of the European Parliament and of the Council of 26 February 2014 on the harmonisation of the laws of the Member States relating to equipment and protective systems intended for use in potentially explosive atmospheres (OJ L 96, 29.3.2014, pp. 309-356)

[2] PN-EN 1127-1:2011 Explosive atmospheres. Explosion prevention and protection - Part 1: Basic concepts and methodology.

[3] Anetor L., Odetunde C., Osakue E., Computational Analysis of the Extended Zeldovich Mechanism, "Arabian Journal for Science and Engineering", 2014, 39, 8287-8305.

[4] PN-EN 60079-1:2014 Explosive atmospheres - Part 1: Equipment protection by flameproof enclosures ' $d$ '.

[5] PN-EN 60079-1:2010 Explosive atmospheres - Part 7: Equipment protection by increased safety ' $\mathrm{e}$ '.

[6] PN-EN 60079-11:2012 Explosive atmospheres - Part 11: Equipment protection by intrinsic safety ' $i$ '.

[7] PN-EN 60079-18:2015 Explosive atmospheres - Part 18: Equipment protection by encapsulation ' $m$ '.

[8] PN-EN 60079-5:2010 Explosive atmospheres - Part 5: Equipment protection by powder filling ' $q$ '.

[9] PN-EN 60079-6:2010 Explosive atmospheres - Part 6: Equipment protection by oil immersion 'o'.

[10] PN-EN 60079-2:2010 Explosive atmospheres - Part 2: Equipment protection by pressurized enclosures ' $\mathrm{p}$ '.

[11] PN-EN 60079-13:2011 Explosive atmospheres - Part 13: Equipment protection by pressurized room ' $p$ '.

[12] Gardner J., Dixon F., Purged and Pressurized Systems for Class I, Div. 1 \& 2, and Zone 1 \& 2 Hazardous Locations, [in]: 2006 Record of Conference Papers - IEEE Industry Applications Society 53rd Annual Petroleum and Chemical Industry Conference, 2006, 1-6.

[13] Ahirwal B., Vishwakarma R.K., Singh A.K., Sinha A., Study of minimum overpressure location on high tension purged and pressurized protected Ex ' $p$ ' motor for explosive atmospheres, "International Journal of Electrical Power \& Energy Systems" 2012, 41, 120-123.

[14] Rong X., Song R., Song X., Li Y., Mechanism and Explosion-proof Design for a Coal Mine Detection Robot, "Procedia Engineering" 2011, $15,100-104$.

[15] PN-EN 60695-11-10:2014 Fire hazard testing - Part 11-10: Test flames $-50 \mathrm{~W}$ horizontal and vertical flame test methods.

LT. SZYMON PTAK, PH.D. ENG. - graduated from the Main School of Fire Service in 2011. In 2016 he received a Ph.D. degree in chemical technology in the West Pomeranian University of Technology in Szczecin. Currently, he holds the position of the Head of the Power Engineering Department at the Main School of Fire Service in Warsaw. Scientific interests: explosion protection, mechanical engineering. 